УДК 633.1: 339.13

\title{
MARKETING STRATEGY FOR DEVELOPMENT GRAIN COMPLEX AGRICULTURE OF UKRAINE
}

\author{
G. Kundieieva \\ National University of Food Technologies \\ O. Kulish \\ PC "State Food and Grain Corporation of Ukraine"
}

\begin{tabular}{|c|c|}
\hline Key words: & ABSTRACT \\
\hline $\begin{array}{l}\text { Marketing strategies } \\
\text { Food sufficiency } \\
\text { Grain complex } \\
\text { Export of flour } \\
\text { GDP of the country }\end{array}$ & $\begin{array}{l}\text { The article considers the issues of strategic development of } \\
\text { the grain complex of the country's agrarian sector. To } \\
\text { ensure the efficiency and competitiveness of economic } \\
\text { activity of grain processing enterprises, a marketing strategy } \\
\text { for development is proposed, which takes into account the }\end{array}$ \\
\hline $\begin{array}{l}\quad \text { Article history: } \\
\text { Received } 14.05 .2017 \\
\text { Received in revised form } \\
29.05 .2017 \\
\text { Accepted } 16.06 .2017\end{array}$ & $\begin{array}{l}\text { state's food sufficiency. The features that should be taken } \\
\text { into account when developing the marketing strategy of } \\
\text { agro-industrial enterprises are singled out. It is determined } \\
\text { that correctly designed marketing strategy of the enterprises } \\
\text { of the grain complex is the fundamental basis of their }\end{array}$ \\
\hline $\begin{array}{l}\text { Corresponding author: } \\
\text { G. Kundieieva } \\
\text { E-mail: } \\
\text { npnuht@ukr.net }\end{array}$ & $\begin{array}{l}\text { development and allows the state to increase the export of } \\
\text { products with higher added value, which also contributes to } \\
\text { the country's GDP growth due to the increase in net exports. }\end{array}$ \\
\hline
\end{tabular}

DOI: $10.24263 / 2225-2924-2017-23-4-12$

\section{MАРКЕТИНГОВА СТРАТЕГІЯ РОЗВИТКУ ЗЕРНОВОГО КОМПЛЕКСУ АГРАРНОГО СЕКТОРУ УКРАїнИ}

\section{Г.О. Кундєєва}

Національний університет харчових технологій

О.А. Куліш

ПАТ «Державна продовольчо-зернова корпораџія Украӥни»

У статті розглянуто питання стратегічного розвитку зернового комплексу аграрного сектору краӥни. Для забезпечення ефективності і конкурентоспроможності господарської діяльності зернопереробних підприємств запропонована маркетингова стратегія розвиту, що враховую продовольчу достатність держави. Виокремлено особливості, які необхідно враховувати при розробиі маркетингової стратегії агропромислових підприсмств. Визначено, що правильно розроблена маркетингова стратегія підприємств зернового комплексу є фундаментальною основою їх розвитку та дає змогу державі збільшити експорт продукиї з більшою доданою вартістю, щзо також сприяє зростанню ВВП крайни за рахунок збільшення чистого експорту. 
Ключові слова: маркетингові стратегії, продовольча достатність, зерновий комплекс, експорт борошна, ВВП краӥни.

Постановка проблеми. Аграрний сектор України є важливою складовою національної економіки, це один з провідних важелів сталого економічного розвитку країни, роль якого особливо посилилася на етапі входження нашої держави у світовий економічний простір. Зернове виробництво належить до стратегічних галузей будь-якої держави і слід зазначити, що протягом тривалого періоду Україна за показником виробництва зернових на душу населення належала до першої десятки країн світу.

На сучасному етапі розвитку зернового ринку країни спостерігаються тенденції випередження темпів виробництва зерна над темпами розвитку внутрішнього ринку. Крім того, останнім часом набуває все більшої актуальності виробництво достатньої кількості зерна не лише для забезпечення внутрішніх потреб держави, а також для зміцнення позицій України на світовому ринку. Політичні та економічні зміни, що відбуваються в нашій країні, примушують продовжувати пошук перспективних напрямів розвитку зернопродуктового ринку.

У підвищенні ефективності зернового комплексу аграрного сектору країни як цілісної багатофункціональної системи найбільш перспективним напрямом $є$ концепція маркетингу, що дає змогу вирішити цілий ряд актуальних проблем. Маркетинг необхідно розглядати як цілісну концепцію управління, оріснтовану на досягнення власних цілей через задоволення попиту споживачів.

Аналіз останніх досліджень і публікацій. Проблемам маркетингу, насамперед питанням формування та вибору адекватної маркетингової стратегії, присвячено праці багатьох вітчизняних та зарубіжних учених, серед яких слід виділити . Ансоффа, Г.Л. Азоєва, Г.Л. Багієва, Ч. Барнарда, М. Вебера, В.Г. Герасимчука, С.П. Голубкова, І.М. Герчикову, В.М. Гриньову, Ю.Б. Іванова, Ж. Ламбена, Ф. Котлера, В.С. Пономаренка, М. Портера, О.І. Пушкаря, Р.А. Фатхутдінова, Г. Черчілля. Актуальним питанням розвитку ринку зерна та зернопродуктів присвятили свої дослідження вітчизняні науковці, такі як: В.І. Бойко,С.В. Кваша, Ю.Я. Лузан, С.В. Майстро, П.М. Макаренко,Л.В. Молдаван, Б.Й. Пасхавер, П.Т. Саблук, О.Г. Шпикуляк та ін. Напрацювання цих вчених надало можливість сформулювати теоретичні та практичні рекомендації щодо удосконалення функціонування зерновиробництва в країні. Разом 3 тим ряд питань визначення вибору ефективних форм і напрямів формування маркетингових стратегій підприємств в умовах реформування економіки залишаються недостатньо вивченими.

Метою статті $\epsilon$ обгрунтування необхідності розробки та застосування маркетингових стратегій розвитку зернового комплексу аграрного сектору України в умовах посилення глобальної конкуренції.

Викладення основних результатів дослідження. Сучасні умови господарювання вимагають від вітчизняних агропідприємств швидкого реагування на зміну ринкової ситуації, підпорядкування виробництва потребам ринку. Необхідність реалізації пов'язаних з цим проблем обумовлює розробку маркетингових стратегій, оскільки середовище, в якому працюють нинішні 
підприємства, стає все більш нестабільним і невизначеним. Аграрний сектор України за останні десятиліття активно розвиває прогресивні напрямки як у виробничій, так і обслуговуючій його сферах. Зокрема, орієнтація на організаційні структури провідних європейських та американських компаній, змушує агропідприємців України працювати в напрямку прорахунку міжнародних показників діяльності, розробки планів, місій та стратегій компанії. Адже вдосконалення стратегії, бізнес-аналітики, поліпшення менеджменту і прогнозування створює шанс на досягнення найвищих показників.

Важливим елементом побудови успішної компанії є розробка маркетингової стратегії як узагальненої моделі довгострокового курсу дій щодо маркетингової діяльності у вигляді системної сукупності визначених перспективних цілей (пріоритетів) і способів (рішень) їх реалізації через використання ресурсів [1]. Активне використання поняття «маркетингова стратегія» сприяє збільшенню доходів вітчизняного агробізнесу, що вказує на доцільність використання цього поняття державою, зокрема Міністерством АП та продовольства України. Сьогодні економічно доцільно розвивати виробництво готового товару і аграрний сектор може забезпечувати експорт не тільки сировини, а й продукції; тому доречно вивчати ринки, потреби, конкурентів, розвивати виробництва продовольчої продукції та будувати маркетингові стратегії, але виходячи з забезпечення продовольчої достатності. Для цього нами запропонований підхід маркетингового позиціонування галузей агросектору за критерієм задоволення фізіологічної норми споживання. Першочергово нами проаналізовано динаміку виробництва певних продуктових груп, що визначають стан продовольчої безпеки країни й для визначення стратегічної позиції кожної з них запропонована модель у вигляді матриці «темп зростання пропозиціі//темп зростання попиту продовольства» (рис. 1).

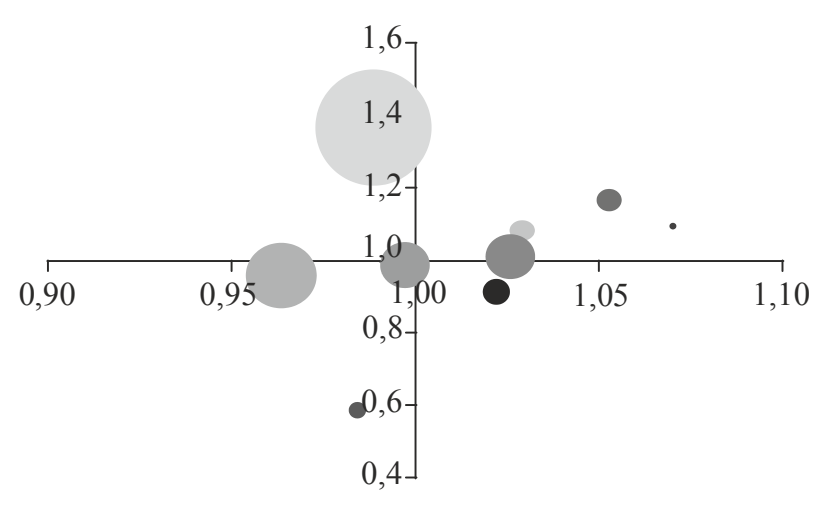

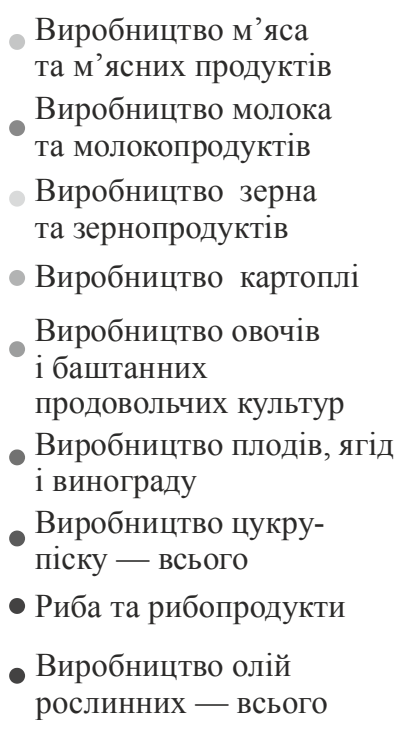

Рис. 1. Матриця визначення стратегічної позиції кожної продуктової групи (агросектор України, розраховано за даними 2015 р.) [2] 
У запропонованій матриці використовуються такі показники: «темп зміни обсягів виробництва» певної продовольчої групи, «темп зміни обсягу споживання» зазначеної продовольчої групи. Матриця складається з чотирьох квадрантів:

- перший квадрант (одночасно зростає і виробництво і споживання i-ï продовольчої групи) - визначення потенційних галузей, орієнтованих на імпортозаміщення;

- другий квадрант (зростає виробництво $i$-ї групи продовольства, а обсяг споживання даної групи знижується) - визначення потенційних експортоорієнтованих галузей;

- третій квадрант (зменшується обсяг виробництва і обсяг споживання $i$-ї групи продовольства) - зона антикризового державного регулювання;

- четвертий квадрант (зменшується обсяг виробництва, а обсяг споживання $i$-ї групи продовольства зростає) — зона державної підтримки виробників.

Дана модель дає змогу визначитися з напрямами розвитку, враховуючи тенденції попиту і пропозиції. Але, на нашу думку, рекомендації щодо обрання стратегії збільшення або зменшення обсягів виробництва певної групи продовольства повинні бути скореговані на такий індикатор продовольчої безпеки, як достатність споживання окремого продукту. Тобто необхідно визначити три сектори виробництва харчових продуктів за показником задоволення попиту (фізіологічну норму споживання):

- перший - галузі харчової промисловості, ринок яких задовольняє фізіологічну норму споживання по $i$-й продовольчій групі;

- другий - галузі харчової промисловості, ринок яких задовольняе раціональну норму, але менше за фізіологічну норму споживання по $i$-й продовольчій групі;

- третій - галузі харчової промисловості, ринок виробництва не задовольняє раціональну норму споживання по $i$-й продовольчій групі.

Відповідно до запропонованої методики визначення стратегічної галузі інтерпретація результатів аналізу вітчизняного агросектору наведені на рис. 2 .

\begin{tabular}{|c|c|c|c|c|}
\hline $\begin{array}{c}\text { Умова споживання } \\
\text { основних } \\
\text { продовольчих груп }\end{array}$ & Перший квадрант & Другий квадрант & Третій квадрант & $\begin{array}{l}\text { Четвертий } \\
\text { квадрант }\end{array}$ \\
\hline $\begin{array}{c}\text { Перший сектор } \\
\text { задовольняє } \\
\text { фізіологічну норму }\end{array}$ & & $\begin{array}{c}\text { виробництво } \\
\text { зерна (хліб та } \\
\text { хлібопродукти) }\end{array}$ & \begin{tabular}{|c|} 
виробництво олії \\
рослинної, \\
виробництво \\
овочів і баштанних
\end{tabular} & $\begin{array}{c}\text { виробництво } \\
\text { картоплі }\end{array}$ \\
\hline $\begin{array}{c}\text { Другий сектор } \\
\text { задовольняє } \\
\text { мінімальну норму }\end{array}$ & \begin{tabular}{|c|} 
виробництво м’яса \\
та м'ясопродуктів, \\
виробництво риби \\
та рибопродуктів \\
\end{tabular} & & & $\begin{array}{c}\text { виробництво } \\
\text { цукру }\end{array}$ \\
\hline $\begin{array}{c}\text { Третій сектор не } \\
\text { задовольняє } \\
\text { мінімальну норму }\end{array}$ & \begin{tabular}{|c|} 
виробництво моло- \\
ка та молокопро- \\
дуктів, виробниц- \\
тво плодів, ягід, \\
горіхів і винограду \\
\end{tabular} & & & \\
\hline
\end{tabular}

Рис. 2. Матриця маркетингового позиціонування галузей агросектору країни за критерісм задоволення фізіологічної норми споживання [2] 
Для підприємств, виробництво продукції для яких обмежено існуванням фізіологічних меж споживання, розширення ринків можливе за рахунок експорту, але це пов'язано із вирішенням такого питання продовольчої безпеки як незалежність.

Здійснений аналіз зовнішньоекономічної діяльності країни вказує на те, що значне місце у вітчизняному товарному експорті займає продукція агропродовольчого комплексу. За останні роки Україна значно збільшила обсяги експорту продукції аграрного сектору: у 2015 р. експорт продукції склав 12\% ВВП країни. За даними ФАО Україна зайняла 25 місце в світі за обсягом експорту цієї продукції, але структура експорту вкрай незадовільна через дуже обмежений асортимент (зернові та олійні займають близько 75\% експорту) [3]. На агропродовольчу продукцію у 2010-2015 рр. припадало понад 38\% товарного експорту України та його частка стрімко зростає, що зумовлює додатне торговельне сальдо країни.

Найбільший обсяг експорту припадає на продукцію рослинного походження (табл. 1), що у 2012-2015 рр. склав майже половину експорту агропродовольчої продукції. Основна частина продукції, що забезпечує додатне сальдо усієї агропродовольчої продукції у 2015 р., — це продукція рослинного походження, а саме: кукурудза, пшениця, ячмінь, ріпак, соя, соняшник. Це обумовлено тим, що у сфері виробництва зерна Україна має конкурентну перевагу. На думку експертів, вартість виробництва в Україні майже на 50\% менша, ніж у європейських виробників [4].

Таблиця 1. Структура експорту-імпорту продукції АПК України у 2010-2015 pp., складено авторами на основі [5]

\begin{tabular}{|c|c|c|c|c|c|c|c|c|c|c|c|c|}
\hline Показник & \multicolumn{5}{|c|}{ Експорт } & \multicolumn{6}{c|}{ Імпорт } \\
\hline Код і назва товарів & 2010 & 2011 & 2012 & 2013 & 2014 & 2015 & 2010 & 2011 & 2012 & 2013 & 2014 & 2015 \\
\hline $\begin{array}{c}\text { I. Живі тварини; } \\
\text { продукти } \\
\text { тваринного } \\
\text { походження }\end{array}$ & 7,76 & 7,31 & 5,36 & 6,36 & 6,09 & 5,65 & 21,55 & 16,31 & 22,77 & 23,14 & 18,55 & 15,73 \\
\hline $\begin{array}{c}\text { II. Продукти } \\
\text { рослинного } \\
\text { походження }\end{array}$ & 40,02 & 43,20 & 51,51 & 52,09 & 52,41 & 54,74 & 32,89 & 28,61 & 32,35 & 32,61 & 33,53 & 32,89 \\
\hline $\begin{array}{c}\text { III. 15 Жири та } \\
\text { олії тваринного } \\
\text { або рослинного } \\
\text { походження }\end{array}$ & 26,34 & 26,53 & 23,52 & 20,58 & 22,93 & 22,66 & 5,23 & 7,38 & 5,41 & 4,93 & 4,98 & 5,23 \\
\hline $\begin{array}{c}\text { IV. Готові харчові } \\
\text { продукти }\end{array}$ & 25,88 & 22,95 & 19,61 & 20,96 & 18,58 & 16,95 & 46,14 & 47,69 & 39,47 & 39,32 & 42,94 & 46,14 \\
\hline
\end{tabular}

В одому із секторів аграрного сектору - виробництво та реалізація зернових, дійсно маємо активне зростання в реалізації сировинної бази с/г культур. Проаналізувавши виробництво пшениці в частині внутрішньої потреби, експорту та надлишків в динаміці 2010/2011-2016/2017МР (рис. 3), можна відзначити, що досить сталим є показник внутрішньої потреби на протязі зазначеного періоду (10-11 млн тонн), в той час як експорт української пшениці має динамічний показник росту. 


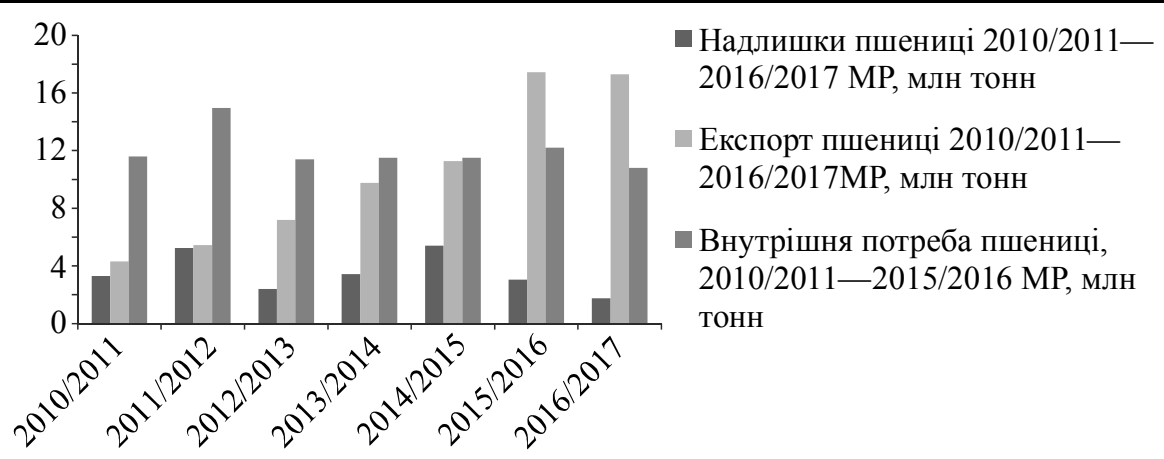

Рис. 3. Динаміка структури реалізації пшениці, складено авторами на основі [6]

Аналіз надходження валютної виручка в розрізі аналітичного періоду свідчить про те, що за даними Держстату в 2010-2017 рр. частка валютної виручки за зернові зростала в динаміці від 10\% до 16\% до загального обсягу (рис. 4).

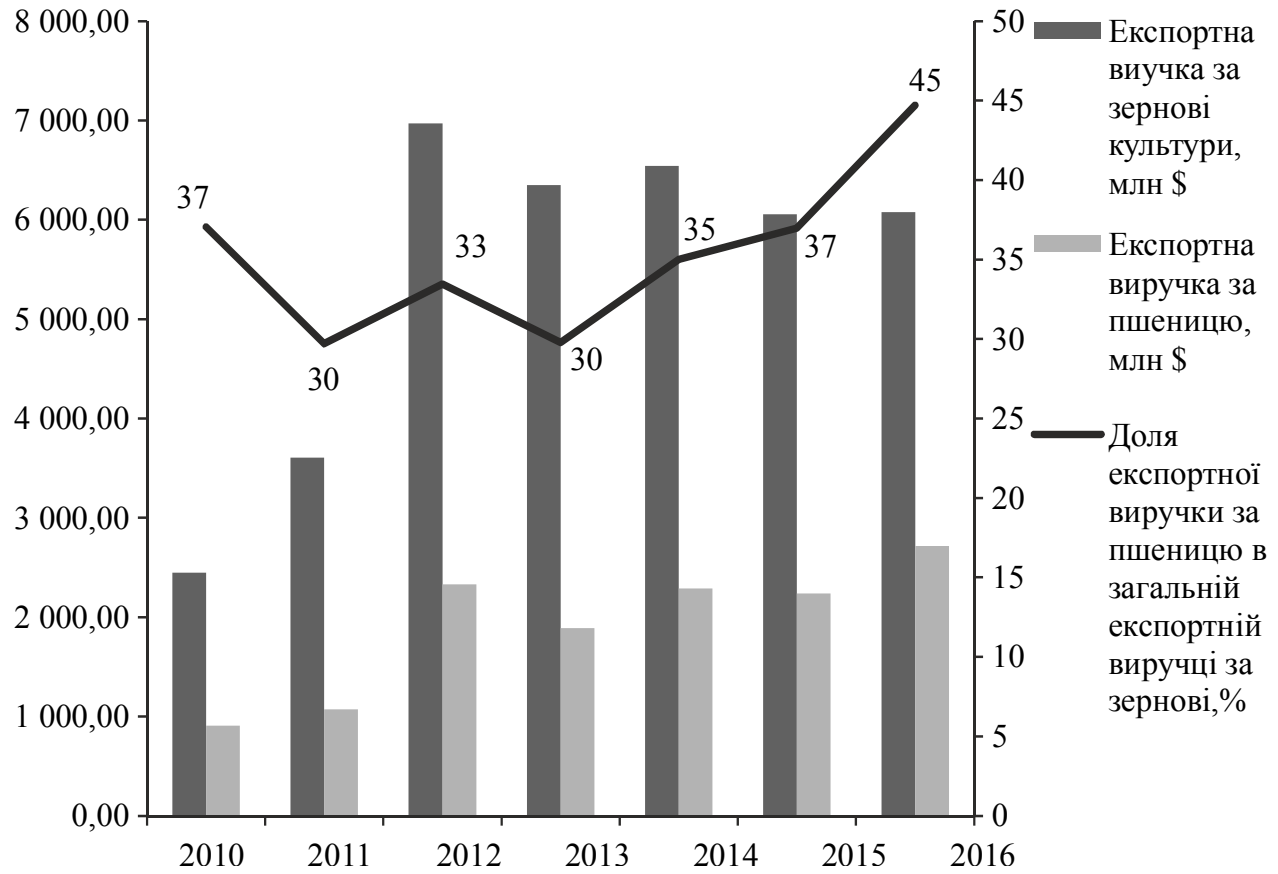

Рис. 4. Частка експортної виручки за пшеницю в загальній експортній виручці за зернові, \%, складено авторами на основі [7].

Фактично за цей період активно розвивалася сировинний сегмент експортних можливостей. Проте нині особливого значення для економічного розвитку країни набуває питання збільшення вітчизняного виробництва 3 високою доданою вартістю. Майбутне полягає в експорті готової продукції, тому у питанні побудови маркетингової стратегії в агросекторі на фоні росту експорту пшениці доцільно розглянути експортні можливості реалізації борошна. 
Нами здійснено аналіз експорту борошна, який свідчить про сталу тенденцію зростання (рис. 5).

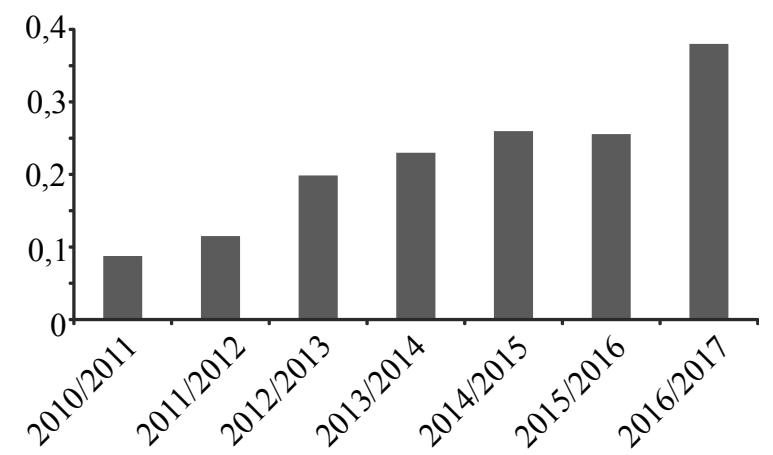

Рис. 5. Динаміка експорту борошна, 2010/2011-2015/2017МГ, млн тонн, складено авторами на основі [8].

Аналітичні розрахунки вказують на те, що фактично кожна реалізована тонна борошна додатково приносить на 100 дол. США більше валютної виручки порівняно з експортом пшениці. Проте виробничі потужності 3 виробництва борошна зорієнтовані виключно під внутрішню потребу (рис. 6), при реальних виробничих потужностях 8 млн тонн.

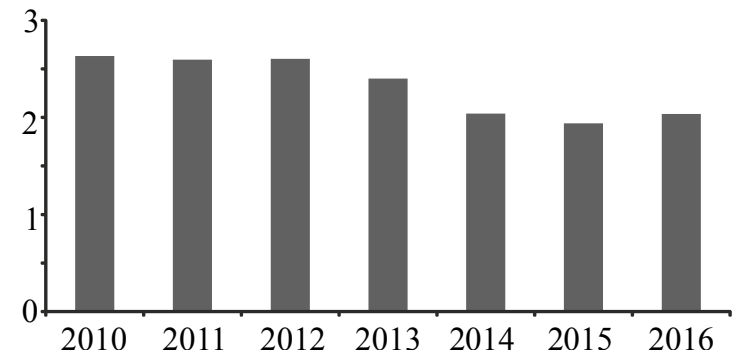

Рис. 6. Динаміка виробництов борошна 2010-2016, млн тонн, складено авторами на основі [8].

Підсумовуючи вищевикладене, можно стверджувати про доцільність збільшення експорту борошна. Проте для заміщення об'єму експорту пшениці в близькій перспективі об'ємом експорту борошна необхідно враховувати визначені традиції ринку: обмежений сировинний ринок; забезпечення продовольчої безпеки країни; монополізація світового ринку борошна; цінова політика; зниження якісних показників вітчизняної сировинній базі.

\section{Висновки}

Розробка державної Стратегії маркетингового планування надасть можливість спрямувати зерновий комплекс на виробництво та експорт українського борошна. Для формування маркетингової стратегії макроекономічного рівня доцільно стимулювати ринок борошна на рівні держави. Насамперед чіткими законодавчими нормативами (для збереження продовольчої безпеки), інвестиційними проектами, квотами на експорт (виключно експорт борошна). Не 
зменшуючи можливості експорту пшениці, можливо задіяти для розвитку експорту борошна саме надлишки виробленої пшениці за умови, що тільки 5\% від надлишків пшениці є придатними для виробництва борошна, Україна не доотримала за 2015/2016 рік 20 млн дол.. США валютної виручки. Додаткова валютна виручка, сталий розвиток виробництв, відсутність клейма «сировинна» держава — стане запорукою росту ВВП.

\section{Література}

1. Бондаренко Л.М. Маркетингова стратегія розвитку молочного підкомплексу регіонального АПК / Л.М. Бондаренко // Збірник наукових праць ЧДТУ. - Серія : Економічні науки. - Вип. 40. - Ч. 1. - 2015. - С. 98-105.

2. Кундєєва Г.О. Продовольча безпека країни: харчова промисловість / Електронне наукове фахове видання «Ефективна економіка». — 2015. — № 12 [Електронний ресурс]. Режим доступу : http://www.economy.nayka.com.ua/?op=1\&z=5011.

3. Нелеn B.M. Пріоритети при формуванні продуктово-ринкової стратегії агропродовольчого комплексу України / В.М. Нелеп, О.М. Висоцька [Електронний ресурс]. Режим доступу : http://ir.kneu.edu.ua:8080/bitstream/2010/7140/1/Prod_res_2014_3_13-19.pdf.

4. Політика щодо інвестування у сільське господарство:Україна [Електронний ресурс]. Режим доступу http://www.oecd.org/globalrelations/Agricultural_Investment_Policies_Ukraine_UKR.pdf Competitiveness and Private Sector Development: Ukraine Sector Competitiveness Strategy, OECD Publishing.

5. Официальный сайт [Электронный ресурс]. — Режим доступа: http://www.ukrstat.gov.ua/.

6. Официальный сайт [Электронный ресурс]. - Режим доступа: http://www.grainsusda.agrochart.com/ru/?report $=58 \&$ commodity $=1 \&$ region $=\&$ country $=213 \&$ attribute $=23$.

7. Официальный сайт [Электронный ресурс]. - Режим доступа: http://www.trademap.org/Country_SelProductCountry_TS.aspx?nvpm=1|804||||1001|||4|1|1|2|2|1|2|2|1.

8. Сакиркин С.В. Доклад II Міжнародної конференції «Форум зернопереработчиков: рынок и технологи - 2016» [Електронний ресурс]. - Режим доступу : http://www.apkinform.com/ru/conferences/forumgrainprocessors/about. 